\title{
La producción literaria de Mercedes Salisachs: una oportunidad para la reflexión moral
}

\author{
The Literary Production of Mercedes Salisachs: \\ an Opportunity for Moral Reflection
}

\author{
M. ${ }^{\text {a }}$ Cristina Pena Mardaras \\ Universidad de Deusto \\ cristina.pena@deusto.es
}

ORCID iD: http://orcid.org/0000-0002-2933-5571

\section{RESUMEN}

El objetivo de este artículo es mostrar cómo las obras de Mercedes Salisachs pueden incluirse entre aquellas que Martha Nussbaum considera aliadas de la filosofía moral porque permiten la indagación sobre cuestiones que son también objeto de la filosofía práctica. Tomando como referencia el proyecto ético-literario de Nussbaum, se explora cómo en las obras de Salisachs el contenido temático de las historias narradas y el modo en que se dispone el discurso interpelan al lector que, inmerso en la experiencia de los personajes, puede reflexionar sobre el horizonte de lo humano en la vida personal y en la vida pública.

Palabras Clave: filosofía práctica; literatura; Mercedes Salisachs; Martha Nussbaum.

\section{ABSTRACT}

The aim of this article is to show how Mercedes Salisachs' works may be included among those that Martha Nussbaum considers moral philosophy allies because they allow the inquiry into issues that are also the subject of practical philosophy. Taking as reference the Nussbaum ethic-literary project, we explore in Salisachs' works how the thematic content of the histories and the way plots are displayed challenge the reader who, immersed in the experience of the characters, can reflect on the horizon of what is human in personal life and in public life.

Key words: Practical Philosophy; Literature; Mercedes Salisachs; Martha Nussbaum.

\section{INTRODUCCIÓN}

En las últimas décadas se aprecia un creciente interés entre algunos autores pertenecientes al ámbito filosófico por establecer una relación fructífera entre

Copyright: (C) 2017 CSIC. Este es un artículo de acceso abierto distribuido bajo los términos de una licencia de uso y distribución Creative Commons Attribution (CC-by) España 3.0. 
la reflexión sobre la vida moral y la literatura ${ }^{1}$. La discusión sobre los diversos modos de entender esta relación y el hecho mismo de su pertinencia no es un tema nuevo. Desde los inicios de la filosofía occidental la relación entre la filosofía práctica y la tradición literaria ha sido una cuestión controvertida: mientras Platón quería expulsar a los poetas de su república ideal por considerarlos perjudiciales para la formación del ciudadano, Aristóteles recurría a ellos para ilustrar sus tratados éticos ${ }^{2}$. A lo largo del sinuoso camino de sus encuentros y desencuentros, la filosofía no ha dejado de preguntarse por el hombre y el sentido de su hacer y su quehacer, y la literatura ha mostrado, de muchos modos, al hombre en acción en mundos ficticios que bien pudieran ser posibles. Juntas o separadas, la filosofía práctica y la literatura han compartido el objeto de su interés ${ }^{3}$. Y es que el hombre se dice a sí mismo y se muestra a los otros en los relatos. Y la comunidad - tribal, social, política - que comparte esas narraciones, no solo se expresa sino que también se configura a través de ellas

${ }^{1}$ El emerger del interés en el campo filosófico por la relación entre ambas disciplinas se manifiesta en la cantidad de publicaciones sobre crítica ética, especialmente en el ámbito anglosajón. Véase, a este respecto, Mendelson-Maoz (2007: 111-116). Por su parte, también en el entorno literario algunos críticos afirman la pertinencia de una aproximación entre ambas disciplinas. Resulta de particular interés la postura sostenida por Wayne C. Booth en The Company We Keep: An Ethics of Fiction, que se distingue de las tendencias mantenidas en los estudios literarios durante gran parte del siglo XX. Recuperando el concepto antiguo de lo ético, legitima la perspectiva y la dimensión ética de la escritura y de la lectura y define la tarea de la crítica ética: «La crítica ética intenta describir los encuentros del ethos de un narrador con el ethos del lector o el oyente. Los críticos éticos no necesariamente tienen desde el comienzo la intención de valorar, pero sus descripciones siempre acarrearán apreciaciones sobre el valor de lo descrito: los términos éticos neutros no existen, y una crítica ética, plenamente responsable, hará explícitas aquellas apreciaciones que están implícitas siempre que un lector $\mathrm{u}$ oyente se refiere a historias relativas a seres humanos en acción» (2005: 20).

2 En República X 607b1-6 Platón atestigua que la discrepancia (diaphorá) entre la filosofía y la poesía es antigua y, en nombre de la razón, reclama para el nuevo discurso filosófico la función educadora que tenía el drama clásico. En el polo opuesto, Aristóteles, en sus tratados éticos, se sirve de la tradición literaria, especialmente de la epopeya y la tragedia, como un modo de experiencia compartida que implica no solo a aprehensión de verdades éticas fundamentales sino también una respuesta emocional adecuada tal como justifica en la Poética $(6,1450 \mathrm{a} 16-17 ; 13,1552 \mathrm{~b} 32-1553 \mathrm{a} 6)$. La estima que le merecen es atestiguada por el hecho de que solo en la Ética a Nicómaco hay cerca de medio centenar de alusiones a obras de Homero, Hesíodo, Eurípides, Sófocles, Teognis y otros literatos.

${ }^{3}$ En su obra conjunta Truth, Fiction and Literature, Peter Lamarque y Stein Haugom Olsen afirman que «the interest which literature has for human beings, it has because it possesses a humanly interesting content, because what literature presents or says concerns readers as human beings» (1996: 265). Es ese contenido humanamente interesante, en el cual reside el aspecto mimético de la literatura, el que le confiere su prominencia cultural y permite una valoración sobre diversos modos de realización de la existencia humana. 
aceptando y rechazando valores y entendiendo la vida en un determinado sentido.

Hay buenas razones para prestar atención y recuperar toda la potencialidad reflexiva y dialógica de la literatura. Por una parte, en una época de profundo cambio como la nuestra, en la que al fracaso de los sistemas unitarios y de los metarrelatos se suma el ritmo acelerado de la vida cotidiana, la buena literatura propicia la reflexión moral en un marco lúdico y no dogmático. A esta razón, de carácter práctico, se añade otra de naturaleza teórica: la necesidad de volver la mirada sobre la vida buena atendiendo a lo concreto, a los contextos en los que el hombre vive y decide en la variabilidad de sus circunstancias. Son estos contextos los que enmarcan su horizonte de sentido y confieren inteligibilidad a la praxis humana que siempre es una realidad situada.

En esta dirección apunta el proyecto ético-literario de Martha Nussbaum:

Imagino [...] un futuro, en el que nuestro modo de hablar sobre la literatura vuelva a interesarse, cada vez más, por lo práctico: por las cuestiones éticas y sociales que hacen que la literatura sea sumamente importante en nuestras vidas. [...] En definitiva, un futuro en el que la teoría literaria (sin olvidar sus muchos otros desempeños) se alíe con la teoría ética para abordar la pregunta: ‘Cómo se debería vivir?' (Nussbaum, 2005: 310)

Esta autora, reconocida por la profunda conexión de sus propuestas filosóficas con otros campos del conocimiento como son el derecho, las ciencias políticas, la psicología, la economía o la literatura, defiende la necesidad de conceder un papel a esta última — particularmente a la novela- en el seno de la filosofía práctica. Justifica su proyecto de «recuperar, en el dominio de la ética, amplia e inclusivamente interpretada, el sentido de la conexión profunda entre forma y contenido que animaba la vieja disputa» entre poetas y filósofos (2005: 58-59), en la consideración de que «determinadas verdades sobre la vida humana solo pueden expresarse apropiada y precisamente en el lenguaje y las formas características del artista narrativo» (2005: 28) ${ }^{4}$. Así, frente a la postura racionalista representada en la vieja querella por Platón y por su deseo de hacer de la ética una teckné que permitiera el control de la vida humana ${ }^{5}$, Nussbaum, con Aristóteles, sostiene una concepción de la naturale-

\footnotetext{
${ }^{4}$ Nussbaum asume en esta obra y, extensivamente, en sus otros trabajos, la concepción de James para quien son artistas todos los que escriben sobre la vida preocupándose de sus elecciones formales y de lo que estas expresan (2005: 29-30).

${ }^{5}$ Desde su primer estudio sobre la ética en la tragedia y la filosofía griega, La fragilidad del bien (1995a), Nussbaum presenta cómo la ruptura de Platón con los poetas y su modo de escribir es manifestación de una profunda crítica moral a la concepción de la vida manifestada en estas. Su escritura, en forma de diálogos que pueden ser caracterizados como un «teatro antitrágico», «expresa el compromiso del filósofo con el intelecto como fuente de verdad [...], estrechamente vinculado a una determinada concepción de la racionalidad
} 
za y la acción humana que requiere del artista narrativo para su total expresión. Son elementos de la misma la importancia existencial de los acontecimientos inesperados, la necesidad de priorizar la percepción del particular (personas y situaciones concretas) sobre las normas universales y abstractas, la relevancia de las emociones en la vida ética y la existencia de valores inconmensurables que a menudo entran en conflicto, haciendo trágica la decisión moral. Por ello, las novelas que en su misma estructura muestran interés por lo cotidiano y descripción detallada del contexto social; atención a la riqueza del mundo interior de los personajes durante períodos largos de tiempo; la condición vulnerable de los mismos y su necesidad de «bienes externos» para una vida plena; la preocupación que supone para ellos los acontecimientos que les acaecen y, en especial, la inquietud por las personas que aman; y los conflictos a los que se enfrentan y la dificultad de dirimirlos a través de sus elecciones, son novelas que, para esta filósofa, pueden servir de aliadas a la filosofía moral no por el hecho de ofrecer determinadas respuestas a la pregunta sobre cómo se debe vivir, sino porque en el modo de narrar instan «a los lectores a advertir esto y no aquello; a ser activo de ciertas maneras y no de otras» guiándole, en definitiva, "hacia ciertas posturas de la mente y el corazón» (1995b: 49) ${ }^{6}$.

El análisis que realiza Martha Nussbaum de algunas novelas - especialmente de James, Proust y Dickens - ejemplifica su modo de entender cómo el sentido de la vida encarnado en la forma de las novelas interpela al lector que, siguiendo el curso de la deliberación y acción de los personajes tal como el novelista los presenta, experimenta emociones que iluminan sus juicios, y puede reflexionar sobre cómo se debería vivir y cuál es el horizonte mismo de lo humano contribuyendo tanto al discernimiento personal como en la vida públi-

humana». En la concepción ética platónica «una parte importante de nuestra humanidad, lejos de ser fuente de claridad, es origen de confusión y precisa ser transcendida mediante la actividad dialéctica del intelecto» (Nussbaum, 2005: 192). La postura aristotélica se opone, en primer lugar, a la concepción platónica, pero también contrasta con otras propuestas que no reconocen el papel de las emociones en la vida ética o quieren subsumir las situaciones particulares bajo normas generales que continúan vigentes en los escritos contemporáneos sobre la elección. Martha Nussbaum escribe pensando, principalmente, en el utilitarismo y el kantismo.

${ }^{6}$ La atención que Martha Nussbaum muestra hacia el modo en que las novelas, en su forma y estilo, muestran un sentido de la vida, encuentra eco - como ella misma reconoceen la obra citada de Wayne Booth en la que el crítico expone su concepto amplio de lo ético y cómo su atención no se dirige a aspectos concretos de las obras sino a la idea de la vida que expresan consideradas como un todo. Subraya Nussbaum la importancia que confiere este autor a la relación que se establece entre el lector y el autor implícito y cómo desplaza su preocupación de las consecuencias de leer - complejas e imprevisibles-, al modo en que las obras conforman los deseos e imaginaciones de los lectores (Nussbaum, 2005: 421-423). 
ca (1995b: 49-50)7. Una actividad ética que no es independiente de la calidad estética de la novela sino que está íntimamente relacionada con su capacidad para suscitar admiración y placer, que atrapa al lector y lo enfrenta a situaciones que, de otro modo, le hubieran resultado más difíciles de abordar8.

Las características de la vida humana que reflejan la concepción expuesta, no son patrimonio exclusivo de las obras analizadas por Nussbaum. En la narrativa española contemporánea, las novelas de Mercedes Salisachs, recientemente fallecida ${ }^{9}$, comparten esa preocupación por la vida del hombre y la seguridad de que las obras de ficción constituyen un modo de interpelar al lector sobre la vida buena. Se trata de una escritora poco estudiada por la crítica $^{10}$

${ }^{7}$ La influencia social y política de la literatura se desarrolla con más profundidad y extensión en Justicia poética. En esta obra Martha Nussbaum defiende la imaginación literaria como un ingrediente esencial de la actitud ética de preocupación por el bien de los demás. Es, por ello, una parte de la racionalidad pública. En palabras de la autora, leyendo novelas «asistimos a la interacción entre las aspiraciones generales humanas y ciertas formas particulares de la vida social que alientan o frustran dichas aspiraciones, modelándolas en el proceso» (1997: 32). Este modo de participación invita a pensar en el desarrollo humano y en nuestra contribución al mismo.

${ }^{8}$ La consideración de que la capacidad de la novela de suscitar reflexión ética y sentimientos morales está directamente relacionada con su capacidad estética, ofrece a Martha Nussbaum un camino para no instrumentalizar el arte. Como señala en Paisajes del pensamiento, la condición artística de la obra produce admiración y placer independientemente de que toque también las emociones eudaimonistas y, por ello, tengan que ver con los intereses del lector relativos a la configuración de la posibilidad humana (Nussbaum, 2008: 284).

${ }^{9}$ Mercedes Salisachs Roviralta falleció en Barcelona el 8 de mayo de 2014. En nota de prensa de 9 de mayo el ministro de Educación, Cultura y Deporte, manifestaba: «Con Mercedes Salisachs desaparece una figura señera de la narrativa española de la segunda mitad del siglo XX, que mantuvo su fecunda actividad creativa hasta el mismo año pasado, en que publicó su última novela. Autora de registro múltiple y de gran versatilidad narrativa, su muerte supone la pérdida de una de las más distinguidas voces femeninas de nuestra literatura» (<http://www.mecd.gob.es/prensa-mecd/actualidad/2014/05/20140509-salisachs.html >). Perteneciente a una productiva generación de mujeres escritoras como Ana María Matute, Carmen Martín Gaite, Carmen Laforet y Elena Quiroga, entre 1955 y 2013 Mercedes Salisachs publicó 28 obras de ficción, muchas de ellas reeditadas y traducidas a varios idiomas, a las que hay que sumar cuentos, algún ensayo, colaboraciones en periódicos y revistas y conferencias en círculos literarios, tanto en España como en el extranjero.

${ }^{10}$ En un homenaje realizado en 2008 por la revista Espéculo, de la Universidad Complutense de Madrid, se subrayaba esta circunstancia constatando que, pese a los premios literarios, las ediciones extranjeras y el éxito editorial desde las primeras obras, en los estudios generales de la novela de la postguerra el nombre de Mercedes Salisachs ni siquiera figuraba en la lista de autores mencionados (Zatlin, 2008). Su nombre y una breve crítica aparecen, en un primer momento, en las obras de Juan Luís Alborj (1962) y José Domingo (1973) a las que hay que sumar dos análisis del conjunto de la obra de Salisachs efectuados una década más tarde: el de la misma Phyllis Zatlin (1987) y el de Janet Pérez (1988). A este elenco tan breve se pueden añadir las referencias en algunos manuales, como el de Valbuena (1983) y el de Pedraza y Rodríguez (2000), las páginas de María Dolores de Asís 
pese a su extensa trayectoria literaria, el reconocimiento del público y el hecho de haber sido galardonada con varios premios ${ }^{11}$. Atenta a las novedades literarias pero, sobre todo, volcada en hacer de sus escritos un instrumento de reflexión y de análisis, refleja en sus novelas al ser humano del siglo $\mathrm{XX}$, en sus contextos concretos y con las dificultades del momento histórico, apuntando problemas y modos de ser y actuar que sobrepasan esos marcos estrechos para remitir al lector al ser humano de todos los tiempos que, tanto en su vida personal como en su interacción en sociedad, no puede soslayar la pregunta ética. En sus obras indaga sobre los condicionamientos que limitan al individuo y las posibilidades de este para actuar dentro de esas condiciones, así como la conciencia de su parte de responsabilidad en la existencia misma de dichas condiciones. En el fondo de todas sus novelas hay una llamada al compromiso con el propio proyecto personal y con la sociedad en la búsqueda de modos de existencia más plenamente humanos y capaces de ofrecer la paz, si no la felicidad.

Es el resultado de una inquietud que ella misma describe como vocación a analizar y reflexionar, al tiempo que pone ante los ojos del lector retazos de vida para que, haciendo la experiencia de los personajes, también reflexione. De ahí que afirme que «escribir no es una finalidad, sino un medio» ${ }^{12}$ en el que se ha sentido profundamente comprometida ${ }^{13}$.

El propósito de este artículo es mostrar cómo la producción de esta autora forma parte de esas obras literarias que Martha Nussbaum califica de potenciales aliadas de la filosofía moral. Lo serán si cada novela, tomada como un todo, ofrece a la consideración del lector los rasgos que definen de modo amplio la concepción ética aristotélica; si —en palabras de Nussbaum-el mismo lenguaje y la forma narrativa expresan dichos rasgos. Para ponerlo de manifiesto se recorrerá un itinerario que, comenzando en la temática de las novelas de

(1996) e Inmaculada de la Fuente (2002) y el comentario de Glenn Morocco y Janet Pérez publicado en una enciclopedia feminista, también en 2002. En la obra de Morocco y Pérez se enfatiza también el poco interés de la crítica pese al éxito comercial de su carrera literaria aseverando que «Salisachs has received slight attention from reviewers and critics, who often labeled her a common writer of comertial middle-class novels - a classification that fails to describe her works accurately or fairly» (2002: 537).

${ }^{11}$ Ha sido galardonada con el Premio Literario Ciudad de Barcelona (1956), el Premio Planeta (1975), del que ha quedado finalista tres veces, el Premio Ateneo de Sevilla (1981), el Premio Fernando Lara (2004) y el Premio Alfonso X «El Sabio» (2009). A título póstumo le ha sido concedida la medalla al mérito en el trabajo (RD 517/2014 de 13 de junio).

12 Mercedes Salisachs. «Vejez y Literatura». Conferencia pronunciada en El Escorial, 6 de septiembre de 2002 (en los archivos de la autora).

${ }_{13}$ En El autor enjuicia su obra Mercedes Salisachs manifiesta la dificultad de todo escritor de hablar con objetividad de sus propias producciones indicando con un lenguaje vivo lo entrañables que le resultan sus obras puesto que para realizar su trabajo «fue preciso vitalizar la sustancia literaria con nuestra propia sustancia humana» (1966: 217). 
Salisachs, ahondará en el modo en que se presenta al lector para fomentar una reflexión que orienta la acción ${ }^{14}$.

\section{LA COMPLEJIDAD DE LA VIDA COMO TEMA DE SUS NOVELAS}

Una mirada superficial puede considerar a Mercedes Salisachs como la gran cronista de la Guerra civil o de la burguesía catalana. Así se han referido a ella con frecuencia articulistas y críticos tras la lectura de alguna de sus obras ${ }^{15}$. El análisis que se realiza en este artículo pretende superar el reduccionismo que se apoya exclusivamente en el ambiente social en el que se enmarcan determinadas novelas y descubrir cómo, tanto considerando cada obra en su particularidad como tomándolas en su conjunto, en el sucederse de las vidas de los personajes emerge una preocupación honda de la escritora por la persona humana y su obrar que, pese a desarrollarse siempre en contextos particulares, apunta más allá de ellos. El discurso teórico que la propia Salisachs ha elaborado sobre sus obras, aunque sucinto, permite descubrir su propósito al escribirlas y el modo en que construye el relato para suscitar la reflexión del lector ${ }^{16}$;

${ }^{14}$ En la estructura de este artículo se respeta la división que la propia Nussbaum hace entre el «contenido» de las novelas, que respondería a su aspecto temático y la propia historia narrada (punto 2), y la «forma» de narrarla (punto 3) que, en terminología de Genette, corresponde al modo de disponer el discurso para la construcción del relato. Se presta así atención a los dos componentes básicos en el nivel de la globalidad del texto. Finalmente (punto 4), se recogen y ejemplifican algunas afirmaciones de Mercedes Salisachs en relación al modo en que la representación de las acciones y acontecimientos, así como la descripción de los personajes, influyen en el lector y facilitan su reflexión. Estas categorías de la narratología moderna, como señala García Landa, tienen su origen en la Poética aristotélica. Pese a la dificultad de realizar una equivalencia estricta, la «historia» puede relacionarse con la acción imitada (praxis), y la disposición de las acciones en el discurso con el mythos (García Landa, 1998: 24-32).

15 Este enfoque de la producción literaria de Mercedes Salisachs es, probablemente, el más extendido, como lo manifiestan las declaraciones a Europa Press del académico de la lengua Pere Gimferrer al conocer su fallecimiento. Destacando que su narrativa «caracteriza perfectamente una época de Barcelona y tiene un valor de documento histórico-literario y sociológico extenso y muy variado» ("Gimferrer define a Salisachs como la "última gran superviviente" literaria de la Guerra Civil», Europa Press. 9 de mayo de 2014, <http://www. europapress.es/catalunya/noticia-gimferrer-define-salisachs-ultima-gran-superviviente-literaria-guerra-civil-20140509134139.html > [ref. de 17/03/2017]), definió a la escritora barcelonesa como «la última gran superviviente literaria de la Guerra Civil» (http://noticias. lainformacion.com/arte-cultura-y-espectaculos/lenguaje/gimferrer-asegura-que-la-obrade-salisachs-tiene-valor-historico-literario-y sociologico_ yEF0uMyItY Jebb8MwAbiI4/). Otras aproximaciones a su producción se han realizado desde la perspectiva feminista o de la novela romántica. Véase Morocco y Pérez (2008: 537-541) y Castillo (1998: 97-125).

${ }^{16}$ En este trabajo, por tanto, aunque se cotejen las afirmaciones teóricas de Salisachs con fragmentos de sus novelas, se ha adoptado la perspectiva del autor real. Deducir el 
y la selección de algunos fragmentos de sus novelas ilustra el modo en que, a lo largo de su extensa trayectoria literaria, ha plasmado su modo de concebir la creación literaria.

Podría afirmarse que es la persona humana, en la variabilidad de sus circunstancias y contextos particulares, la gran protagonista de las novelas de Mercedes Salisachs ${ }^{17}$. Con expresiones diversas y un tanto confusas, tanto en sus propios trabajos críticos sobre sus obras como en conferencias y entrevistas, la escritora se refiere a los personajes y hechos ficticios como «existentes» e «históricos» e invita a la reflexión sobre ellos. En realidad, a lo que está apuntando es a la verosimilitud de la ficción y a la posibilidad de generalización que entraña inscribiéndose, de este modo, en la larga tradición que arranca de Aristóteles y apoya la potencialidad ética de la novela en su evocación de lo que puede $\operatorname{pasar}^{18}$. Intentando identificar qué hace relevantes para nosotros a los personajes históricos y ficticios, se pregunta:

autor implícito en cada una de sus novelas excede la pretensión y extensión de este artículo. Las referencias a las obras de la novelista, pese a no tener afán de exhaustividad, recogen hitos significativos de su trayectoria y la abarcan desde sus inicios con Primera mañana, última mañana (1999; primera edición de 1955), a la última obra publicada, El caudal de las noches vacias (2013).

${ }^{17}$ El interés de Mercedes Salisachs por plasmar los grandes problemas humanos ya fue puesto de relieve en los albores de su trayectoria literaria por el crítico belga, Edmond Vandercamen que, al realizarse la traducción al francés de Una mujer llega al pueblo, escribió: "Aunque los hechos se hallan íntimamente ligados a un cuadro muy limitado de tiempo y de espacio, la significación de esos hechos sale de sí misma para colocarse en el plano universal» (Salisachs, 1966: 228-229). Este interés por reflejar al hombre se manifiesta en la crítica que la autora realiza a la novela del objeto de mediados de siglo, a la que considera deshumanizada (1966: 220).

${ }^{18}$ La conocida afirmación del Aristóteles: «la poesía es más filosófica y elevada que la historia» (Poética 1451b6) muestra cómo la relación entre las ficciones literarias y la filosofía tiene una larga tradición y no es, por tanto, un elemento extraño a la Teoría de la Literatura. Precisamente, al subrayar que el carácter filosófico de la poesía estriba en que la verosimilitud de lo que puede pasar sitúa a la poesía en el terreno de lo general y no de lo particular, en palabras de Antonio Garrido «el Estagirita no solo aparece como patrocinador de una larga tradición que trata de explicar la esencia de la ficción a partir del concepto de mímesis [...] sino que avala incluso las posturas más rupturistas de los últimos decenios: la de los defensores de la posibilidad de una literatura antimimética» (Garrido, 1997: 11-12). Este carácter ficcional de la literatura ha abierto, en el ámbito filosófico, un debate en torno a diversas cuestiones: cómo dar cuenta de la realidad de la ficción, la cuestión referencial y la verdad de la literatura, la relación entre mundo ficcional y mundo real... Una postura consistente con las tesis de Martha Nussbaum y el enfoque de Mercedes Salisachs es la sustentada por Lamarque y Olsen que, en la obra citada, señalan cómo el valor cognitivo de la literatura no reside en la referencialidad sino que tiene una relación estrecha con el modo en que el contenido ficticio es presentado, poniendo ante los ojos del lector contenidos humanamente interesantes. «The point is that fiction can provide an occasion for imaginative reflection that perhaps otherwise would not be available to us. [...] The intuition that 
¿Tendría importancia Napoleón si la vida no estuviera plagada de pequeños napoleones? ¿Dónde reside verdaderamente la transcendencia de D. Quijote? ¿No será en lo que tiene de espejo para la mayoría de los españoles? (1966: 218).

Por esta capacidad de devolver al lector su propia imagen o la de las personas con las que convive, considera la escritora que incluso las novelas mediocres permiten extraer conclusiones dignas de ser analizadas aun cuando su pretensión literaria no se conforme con eso y, además de la verosimilitud, apunte a encontrar la técnica adecuada ${ }^{19}$ para presentar cualquiera de los grandes temas humanos que recorren el horizonte cultural a lo largo de la historia.

Todo en la vida puede ser una llamada de atención para escribir un libro. La novelista barcelonesa indica que cualquier detalle - una noticia leída en un periódico ${ }^{20}$, una persona que deja huella o una experiencia personal hondamente sentida- le incita a «echar fuera lo que está pidiendo convertirse en un relato, en una biografía o en cualquier ensayo más o menos filosófico» (Salisachs, 2003: 99). Todo contribuye a recrear situaciones humanas de las que se sirve para presentar a la consideración del lector el problema que le acucia. «El argumento es sin duda alguna la fuerza externa que permite al lector introducirse de lleno en lo más profundo del tema que el autor describe —afirma-, pero sería verdaderamente lamentable que el autor considerase el argumento más importante que la idea inicial» (2003: 99) ${ }^{21}$. Para ilustrar esta distinción,

fictions are about real people (people in love, politicians, parents, university lecturers, and so forth), other than in the somewhat special cases where an author intends directly to refer to named individuals, can be accommodated without invoking any mysterious "correspondence" relation. By reflecting on fictional content readers can come to see themselves and others under the same aspects that characterize the fictive states of affairs» (1996: 136).

19 Se aprecia una evolución en la reflexión de Mercedes Salisachs entre el capítulo escrito en 1966 y el ensayo de 2003 en relación con lo que hace buena una novela. Además de la extensión y el diverso propósito de ambos escritos, en su «radiografía de mis novelas» - como subtitula La palabra escrita - se aprecia la seguridad que otorga una trayectoria consolidada en la que la autora ha encontrado su estilo, «el realismo, la lógica, y el sondeo del alma humana» (2003a: 58). Subraya el esfuerzo que supone el escribir presentando una contraposición entre inspiración y artesanía e indicando que «más que apoyarnos en la imaginación debemos apoyarnos en la técnica» (2003a: 91).

${ }^{20} \mathrm{La}$ incidencia de las noticias de actualidad en la problemática de sus novelas es clara. En varias entrevistas reconoce pasar un tiempo largo por la mañana leyendo la prensa del día $\mathrm{y}$, en los últimos años, escuchando la lectura de los periódicos cuando ya no podía leer. En relación con la crudeza de algunas de sus historias Mercedes Salisachs afirma: «Nuestra existencia también es cruda. Basta abrir el periódico del día para percatarnos de que nuestra existencia no es un colchón blando, sino un alud de problemas cada vez más espeluznantes» (Ayuso, 2008).

${ }^{21}$ En las páginas que siguen se emplea la nomenclatura que utiliza Mercedes Salisachs tanto en La palabra escrita como en conferencias u otras intervenciones. El argumento de Salisachs, que ella misma califica como un recurso, parece referirse a la acción narrada, esto es a la story de la crítica anglosajona. La escritora indica que «lo esencial en una exposición 
en La palabra escrita esta autora presenta los argumentos y la idea-mensaje de algunas de sus novelas.

El siguiente cuadro muestra dos de los ejemplos que ofrece en dicho ensayo.

FigURA 1

EXTRACTO DE LA PALABRA ESCRITA (2003: 30-32)

\begin{tabular}{|l|l|}
\hline \multicolumn{1}{|c|}{ IDEA-MENSAJE } & \multicolumn{1}{|c|}{ RECURSO-ARGUMENTO } \\
\hline $\begin{array}{l}\text { UNA MUJER LLEGA AL PUEBLO: } \\
\begin{array}{l}\text { Reflejar en un pueblo la atmósfera y las } \\
\text { limitaciones que sufría España en la época } \\
\text { franquista y, como consecuencia, la falta } \\
\text { de solidaridad disfrazada de puritanismo. }\end{array}\end{array}$ & $\begin{array}{l}\text { La llegada de una mujer a su pueblo con } \\
\text { las esperanza de encontrar ayuda, sin con- } \\
\text { seguirlo. }\end{array}$ \\
\hline $\begin{array}{l}\text { LA CONVERSACIÓN: } \\
\text { Refleja los malos tratos que las mujeres } \\
\text { pueden ejercer en algunos hombres sin que } \\
\text { la defensa sea posible. }\end{array}$ & $\begin{array}{l}\text { Un hombre y una mujer que jamás se han } \\
\text { visto, viajan juntos a Estado Unidos La } \\
\text { conversación que mantienen, no solo los } \\
\text { convierte en amigos entrañables, sino que } \\
\text { consigue enamorarlos. Pero el interrogante } \\
\text { que los separa entorpece su verdadera } \\
\text { unión. }\end{array}$ \\
\hline
\end{tabular}

Una mujer llega al pueblo fue publicada en $1956^{22}$ y La conversación vio su primera edición en 2002. La primera novela refleja la sociedad española de los años 50 centrándose en la sociedad rural de un lugar concreto de la geografía española: un pueblo de la Costa Brava. La segunda pone de manifiesto un ambiente cosmopolita unas décadas más adelante. Distantes en el tiempo de publicación y distintas en ambiente e hilo argumental, también los protagonistas principales de ambas novelas son de diverso género: una mujer en la primera y un hombre en la segunda. No obstante, hay temas de fondo en los que ambas coinciden y que no son patrimonio de una época o un lugar determinado sino que, en diferentes formas, impregnan la vida humana de todas las épocas. Por ejemplo, en ambas novelas se pone de relieve la importancia social de guardar las apariencias aunque para ello sea necesario mantener una doble moral:

novelística no es "lo que va a pasar" sino "cómo va a pasar"》 (2003a: 29). Ese cómo es el modo en que organiza el discurso (plot) que se examina en el siguiente apartado.

22 Todas las novelas de Mercedes Salisachs se referencian de acuerdo con la paginación de la edición que figura en la bibliografía citada al final del artículo. 
Lo principal era llegar al pueblo antes de que empezase la procesión; formar parte de la comitiva, poner cara de virgen honesta... No obstante era difícil sentirse honesto después de haber hecho el amor con amor (1999: 283).

[...] su empeño en aparentar ser una mujer feliz y darle un sentido positivo a sus conatos de humillaciones [...]. No sé si su padre la creía. Pero fingía creerla. Era su manera de desentenderse de problemas desagradables que prefería ignorar (2002: 141).

De diverso modo y apuntando en distinta dirección, las dos narraciones ilustran relaciones de violencia y dominio entre el hombre y la mujer:

[Narcisa] llegó a ser para él un temporal constante al que era preciso combatir. Cuando no la tenía la echaba de menos y cuando la sentía presa suya, hubiera querido desgarrarla. [...] No podía definir si la quería. Sabía únicamente que no podía vivir sin ella (1999: 374$)$.

Si presento denuncia contra ti ya puedes irte despidiendo de tu hijo —me lanzó como si me escupiera- En cuanto le enseñe al juez lo que acabas de hacerme, tus heridas de mierda dejarán de tener importancia; una mujer maltratada tiene derecho a defenderse (2002:169).

En los momentos importantes aflora la pregunta tanto por la responsabilidad individual como por la colectiva:

Nadie quiso socorrerla. Su muerte pudo ser evitada, pero nadie, absolutamente nadie, la evitó. La dejamos morir... (1999: 506).

Noches horribles en que los errores cometidos, crecen para que no puedan ser subsanados, antes al contrario, se repiten y se amplían mil veces potenciando su realismo (2002: 209).

Utilizando la terminología de Lamarque y Olsen, podría afirmarse que estas obras abordan «temas perennes» que hacen de ellas «one of the ways in which these existential problems, as well as social and moral values, are defined and developed for us» (1996: 451).

Esta presencia de temas perennes en las novelas de Mercedes Salisachs se manifiesta también en la coincidencia en alusiones de críticos, articulistas y la propia autora en relacionar diversas obras con temas de la mitología griega ${ }^{23}$. Para la escritora, que recurre al conocido aforismo orsiano "todo lo que no es tradición es plagio» ${ }^{24}$, estar en la tradición recreándola requiere «lanzar [...] la

${ }^{23}$ A modo de ilustración puede citarse El último laberinto (2004b), que la propia autora ha calificado como una versión moderna del mito de Teseo (Sánchis, 2003) o la opinión de la crítica sobre Pablo, Fela y Cecilia — personajes de La estación de las hojas amarillas que, esta vez sin pretensión de la autora, fueron considerados personificaciones de Hipólito y Fedra (Salisachs, 1966: 234).

${ }^{24}$ Este aforismo, inscrito en la fachada norte del Casón del Buen Retiro de Madrid, es un extracto de un aforismo más amplio, escrito originalmente en catalán (Salisachs, 
historia en forma de novela de nuestra propia actualidad ${ }^{25}$ » y eso implica presentar fielmente los aspectos de la realidad cuidando los detalles y dibujando todos los ambientes ${ }^{26}$. Un esfuerzo por aprehender todos los sectores de la sociedad y reflejar su tiempo reconocido por los escasos comentarios con carácter académico que se hacen eco de su trayectoria:

Muy claramente, Salisachs quiere ser novelista de su época, mostrándonos los efectos de la guerra y los cambios que se ven tanto en la vida social como en la comercial. [...] Es un importante testimonio social, que presenta el cambio en los papeles de las clases sociales y de los sexos en la España de la postguerra (Zatlin, $2008)^{27}$.

Son pocas las novelas de esta autora que pueden catalogarse como históricas. También estas corroboran que su intención al escribir va más allá de presentar, reconstruir o rehabilitar el pasado y se centra en presentar, contextualizados, los grandes problemas humanos que se mantienen constantes en el devenir de la historia. Así en El declive y la cuesta (2007; primera edición de 1966), ambientada al comienzo de la era cristiana, muestra el dolor y angustia maternos ante el sufrimiento del hijo ${ }^{28}$ y Goodbye España, que narra la vida de la reina Victoria Eugenia de modo autobiográfico, se presenta como la historia de un amor imposible ${ }^{29}$.

Un interés por lo humano que, de modo diverso y apoyado en distintos recursos, se descubre también en las novelas de fantasía, todas ellas de una

1966: 219).

${ }^{25}$ Salisachs, Mercedes. «Una sola semilla para varios frutos». Conferencia pronunciada en Cartagena, 7 de mayo de 2003 (en los archivos de la autora), p. 11 bis. El propósito de mostrar la realidad de su tiempo es explicitado por la novelista en muchas ocasiones. Eso explica el que muchas de sus novelas reflejen con detalle la historia de España. A propósito de algunas dificultades técnicas que encontró en la realización de La estación de las hojas amarillas Mercedes Salisachs señala que «eludir la guerra, cuando la guerra fue un hecho tan importante en nuestra generación, me parecía no solo ilícito sino poco valiente» (1966: 232).

${ }^{26}$ El deseo de dibujar ambientes sociales diferentes al suyo no siempre ha sido valorado por la crítica. Así, cuando publicó Una mujer llega al pueblo, obra reconocida desde el primer momento en el extranjero, en España se minusvaloró diciendo: «es como si un remendón de oficio se hubiera atrevido a escribir una obra sobre la alta sociedad» (Salisachs, 1966: 227). Alborj hace extensiva su valoración negativa de esta novela a La sinfonía de las moscas que cataloga como «un segundo aterrizaje en la vida vulgar: una vida vulgar que la autora evidentemente conoce apenas» (1962: 397).

27 Sobre esta misma cuestión, véase Laguna (2008).

${ }^{28}$ En la contraportada de la edición de 2007 de esta obra se presenta la novela como una «parábola de la condición humana».

${ }_{29}$ «Mercedes Salisachs presenta "Goodbye, España”», Europa Press. 5 de junio de 2009, <http://www.europapress.es/cultura/libros-00132/noticia-mercedes-salisachs-presenta-goodbye-espana-20090605164623.html> [ref. de 17/03/2017]. 
etapa temprana. La pretensión de estimular en el lector una reflexión sobre el ser humano pese al ambiente irreal en que se desarrollan se manifiesta en la interpretación que la propia Mercedes Salisachs hace del protagonista de Más allá de los raíles:

Ese hombre (aparentemente civilizado), un arquetipo sin nombre de una sociedad desflorada y mustia, que, pese a vivir disfrazada de civilización, no vacila en dejar escapar su instinto puramente animal cuando se sitúa más allá de su ética, de los principios inviolables, de su valores eternos... es decir; más allá de los raíles (Salisachs, 1966: 226) ${ }^{30}$.

Lo expuesto hasta el momento permite concluir que los diversos escenarios y las variadas realidades que afloran en las novelas de Mercedes Salisachs (desigualdad de género, falta de libertades, fragilidad del matrimonio, terrorismo, aborto, violencia sexual, adicciones, pederastia, homosexualidad, especulación financiera, religiosidad vacía, prostitución, frivolidad...), no son accidentales sino que pretenden poner ante los ojos del lector las grandes preguntas que han acuciado al ser humano en todos los tiempos. Por eso muchas de ellas, aunque escritas hace décadas, siguen estando de plena actualidad, no en las circunstancias o las valoraciones que presentan sino en los conflictos que reflejan. Lo muestra la reedición reciente de algunas de las novelas de Salisachs que parece motivar una respuesta positiva a la pregunta retórica que ella misma formulaba en relación con las obras de arte: «Si la obra perdura, ¿no será que, a pesar de todo, entrañaba algún punto de verdad y de veracidad?» (Salisachs, 1966: 228).

\section{RE-PRESENTAR LA VIDA: HISTORIA Y DISCURSO EN LAS FICCIONES DE SALISACHS}

La característica de la ficción frente a otros modos de proponer la vida humana y sus grandes cuestiones es que sitúa al lector/espectador en un escenario imaginativo en el que participa de lo que sucede identificándose de algún modo con los personajes ${ }^{31}$.

${ }^{30}$ Esta intencionalidad de la autora no ha sido percibida por todos los críticos. Juan Luís Alborj destaca en esta obra su originalidad y fuerza dramática, «el gesto creador de la novelista que "pone", crea una realidad que no pretende simplemente ser copia de otra realidad exterior» (1962: 393) mientras que José Domingo alaba su superación del realismo (1973: 138).

${ }^{31}$ La participación imaginativa del lector en la ficción es parte de su respuesta a la misma. Como afirma Peter Lamarque en su estudio sobre la ficción y la literatura, «readers "fill in", or just take for granted, an enormous amount of detail which is not explicitly given. A general assumption, for example, is that if characters are human beings then, unless rea- 
Desde los comienzos de su carrera literaria Mercedes Salisachs ha mostrado una gran preocupación por el modo de construir el relato. Así, ya en 1966 aseveraba que «lo esencial no está solo en los hechos que se expone, sino en la forma de exponerlos» (1966: 224) $)^{32}$, cuestión a la que dedica muchas páginas en La palabra escrita consciente de la importancia del equilibrio entre todos los elementos que construyen la obra.

La trayectoria literaria de esta escritora catalana evidencia que no todo modo de narrar se ajusta a sus propósitos al escribir. En El autor enjuicia su obra se refiere a las diversas tendencias literarias del momento cuestionando los frutos del afán renovador de la época y manifiesta su disconformidad con un modo de escribir que no permite ahondar en protagonistas concretos sino que se centra en la masa (Salisachs, 1966: 229-220) ${ }^{33}$. Pese a que también ella, en sus primeros tiempos, realiza incursiones por diversos estilos que califica como pruebas más o menos racionales para descubrir el suyo propio, finalmente encontrará el medio adecuado en la novela realista psicológica ${ }^{34}$.

sons are given to doubt this, they are like ordinary human beings in obvious respects» (Lamarque y Olsen, 1996: 89). Precisamente de esa participación deriva gran parte del placer de la ficción.

${ }^{32}$ Esta preocupación por la adecuación entre el tema y la forma sintoniza con la aseveración de Peter Lamarque quien señala que «the literary work develops theme through literary form, through diction, metaphor, symbol, description of setting, presentation of character, parallels, contrasts, various other features of structure, point of view, etc. It is this merging of theme and form, this emergence of theme from form, that makes literary interpretation of a literary work necessary and literary appreciation possible» (Lamarque y Olsen, 1966a: 436).

33 Años más tarde Mercedes Salisachs insiste en esa crítica indicando que «si el autor no tenía derecho a "opinar" o a "escribir interioridades humanas", escribiendo en primera persona o en segunda persona [...] los relatos reducían sus posibilidades hasta el extremo de arrasar toda riqueza interior y escamotear al lector conceptos importantes» (2003a: 38).

34 Juan Luis Alborj, al comienzo de la carrera literaria de Salisachs, señala que esta autora todavía no ha definido su estilo y destaca su dominio del arte de la narración y sus cualidades para la novela intelectual (1962: 383-397). De esa época son sus novelas de estilo fantástico consideradas también por José Domingo sus mejores creaciones hasta el momento (1973: 137). Sin embargo, Mercedes Salisachs pronto se centró en el realismo, prestando atención tanto a los contextos como al mundo interior de los personajes. En La estación de las hojas amarillas (1982a), publicada por vez primera en 1963, se aprecia un estrecho paralelismo entre la forma novelesca y las estructuras mentales de la protagonista y una fina atención tanto a sucesos como al diálogo interior del personaje. Encarnación Laguna subraya cómo Salisachs es precursora, en esta obra, de algunas técnicas empleadas por Delibes, de quien le consta que pudo leerla antes de que fuera publicada (Laguna, 2008). La novela es casi contemporánea de Tiempo de silencio, de Martín Santos, considerada como iniciadora de la indagación en lo individual en plena vigencia del realismo social y precursora de la instalación, dentro del realismo, de procedimientos experimentales también explorados, incluso con anterioridad, por la novelista catalana. 
A continuación, se expone cómo gestiona en sus novelas algunos de los elementos esenciales para hacer de la historia que narra una obra literaria ${ }^{35}$.

\section{a) El papel del narrador y los personajes: la visión y las voces de la historia.}

Mercedes Salisachs, cuando se refiere al modo de construir sus novelas, no hace un discurso teórico que permita distinguir de modo claro al autor del narrador. Sin embargo, considera de la mayor importancia la decisión sobre la voz en la novela:

Antes de ponernos a escribir una obra, es preciso reflexionar: saber lo que se pretende exponer. Luego meditar cómo vamos a exponerlo y por último pensar en quién se encargará de divulgar esa exposición: ¿El protagonista? ¿El autor? ¿Los distintos personajes? O quizá todos a la vez (2003: 18).

Atendiendo a su propósito de que el lector tenga un papel activo en la búsqueda del significado de la obra, evita toda interferencia del autor entre lo que ocurre en la novela y el lector. Por ello, sus narraciones se desarrollan muchas veces en $1 .^{\mathrm{a}}$ o $2 .^{\mathrm{a}}$ persona e incluso, cuando lo hacen en 3 . $^{\mathrm{a}}$ persona, son los propios personajes los que muestran lo que pasa y describen a sus compañeros $^{36}$.

Los personajes —en palabras de la escritora-, «no solo deben "ser": también deben "hacer" y “estar"» (2003: 146). Por ello, escoger cuidadosamente su carácter forma parte de la labor de artesanía que supone el escribir (2003: 92). Insiste la novelista barcelonesa en que todos deben tener un protagonismo esencial, aunque no sea relevante y que no están sujetos al arbitrio voluble del autor: «cada uno de ellos debe subsistir antes de que el autor se decida a describirlo» (2003: 147) de modo que, en ocasiones, un determinado modo de $\operatorname{ser}^{37}$

${ }^{35}$ El esquema que se va a seguir para ver cómo Salisachs realiza la transformación de la historia en el relato tiene en cuenta la modalización, la temporalización y la espacialización (Villanueva, 1995). Se trata de modo conjunto el papel del narrador y los personajes; a continuación del espacio y el tiempo como coordenadas en que se desarrolla la acción (el cronotopo en palabras de Batjin) y, finalmente, se presta atención al lenguaje poético como un elemento esencial de la obra literaria.

36 «Es [...] el mejor modo de hacer "real" lo que de por si es ficticio» (Salisachs, 2003a: 24) pero requiere una gran pericia técnica. En El autor enjuicia su obra Mercedes Salisachs refiere, entre otras, la dificultad que supuso para ella, cuando escribió La estación de las hojas amarillas mostrar que Cecilia, la protagonista y narradora del relato, estaba equivocada. «A pesar de ser ella la narradora y de esgrimir argumentos particularmente favorables, Cecilia no tenía razón» [cursiva en el original] (1966: 235).

37 Salisachs se refiere a los personajes desde una consideración psicologista, vinculándolos a características de las personas reales con cuya densidad psicológica, expresiva de la complejidad del ser humano, se pueden establecer relaciones. Aunque atiende a la función de cada uno en la estructura de la obra (consideración actancial) la caracterización de los 
puede variar el trazado intelectual que había proyectado el escritor y obligarle a introducir algunos cambios en el relato (2003: 73).

Uno de los recursos de los que se vale en muchas de sus novelas para enriquecer la perspectiva del lector es la combinación de voces narrativas. Como muestra de este multiperspectivismo, aplicado ya no a una novela sino a dos, destaca el modo complementario en que La gangrena (2004a; primera edición de 1975) y Bacteria mutante (1996) abordan la misma historia ${ }^{38}$. Ambas novelas, escritas desde la perspectiva del yo protagonista en que voz y visión se funden, presentan la vida de Carlos Hondero y Lolita Moraldo. Si bien pueden leerse por separado, el contraste entre una y otra aporta matices interesantes y pone de relieve la importancia que la escritora concede a la búsqueda de una mayor objetividad sin dejar de prestar atención a la interioridad de los personajes.

En conjunto, esta es una preocupación que la autora muestra en toda su obra y, tanto en las novelas fantásticas como en las que se califican como de ambiente cosmopolita, es el fluir de la conciencia de los personajes lo que permite adentrarse en su interioridad y participar de su visión de la vida y de su toma de decisiones ${ }^{39}$. El autor, por tanto, y el narrador cuando no es parte de la ficción, quedan «fuera» de algún modo y guían la narración llamando a los personajes a que sean ellos mismos quienes se muestren en la acción o a través de las palabras de los otros personajes.

\section{b) El espacio y el tiempo.}

En la mayor parte de las novelas de Mercedes Salisachs el tiempo del discurso es mucho más breve que el tiempo de la historia. Obras tan conocidas como Una mujer llega al pueblo, La estación de las hojas amarillas, Adagio confidencial, La Gangrena, El volumen de la ausencia, Bacteria mutante, El último laberinto, Goodbye España o El caudal de las noches vacías están escritas con una técnica que permite «meter el tiempo dentro del tiempo» en palabras de la propia autora. La escritora catalana expone que el objetivo de

personajes es un elemento esencial en su concepción de la novela. Sobre los personajes y su modo de ser, véase Salisachs (2003a: 145-149).

${ }^{38}$ El éxito editorial de La gangrena, que cuenta con 58 ediciones, probablemente determinó en que fuera la novela escogida por Salisachs para reelaborar los mismos aspectos temáticos desde una perspectiva diferente. Sin embargo, Bacteria mutante no ha tenido la misma acogida por parte del público y la complementariedad entre ambas novelas ha sido poco estudiada y destacada.

39 Zatlin y algunos comentaristas subrayan el estilo faulkiano de Mercedes Salisachs (Zatlin, 2008). Respecto a la estima que merece a la escritora barcelonesa la técnica de William Faulkner, sus afirmaciones resultan confusas y parecen contradecirse (Salisachs, 1966: 219; cfr. 2003a: 35). No obstante, Faulkner se caracteriza por el drama psicológico y la profundidad emocional, rasgos que críticos como Phyllis Boris Zatlin destacan en Salisachs. 
ese juego con el tiempo es ayudar a que el lector reflexione y comprenda sintiéndose partícipe de lo que ocurre «tanto para "descubrir" lo que el tiempo pasado puede ofrecerle, como para que pueda asimismo "asimilar" mejor el tiempo presente que caracteriza la estructura de la novela» (2003: 45).

Esta participación-reflexión del lector es semejante a la del protagonista cuando desde el presente se sumerge en el pasado: puede tener una mirada sobre la vida más allá de la inmediatez de los acontecimientos en la medida en que la contempla desde fuera, como un todo ${ }^{40}$.

La búsqueda de perspectiva que pretende Salisachs requiere no solo la mirada distanciada que el tiempo proporciona, sino el conocimiento de las circunstancias concretas. El modo de situar al lector en el momento de la narración no se efectúa ofreciendo fechas. Para Mercedes Salisachs el lector debe saber «en cada momento dónde se encuentra; qué ambiente le rodea y sobre todo hasta qué punto el hecho consumado está influyendo en la vida de los personajes» (2003: 55), y es recurriendo a la mención de acontecimientos naturales, sociales y políticos, a hechos acaecidos a un personaje relevante, o a manifestaciones culturales del momento como le sitúa históricamente.

Otro modo de prestar atención al contexto en que se desarrolla la vida de los personajes son los espacios. Pero Salisachs, pese a cuidar sus relaciones con los espacios reales, hace un uso literario del espacio centrado en la dimensión de sentido. Se puede apreciar tanto cuando el narrador se encuentra en un ambiente cerrado, que invita a la introspección (Cecilia en La estación de las hojas amarillas mientras escribe su larga confesión, Carlos en su celda en La gangrena o Eladio en La conversación, a bordo del avión que le lleva a EEUU), como en las referencias a los ambientes en los que se ha desarrollado su vida y que han influido en la historia que muestra. Incluso en obras que recrean fielmente el espacio real, el espacio literario es utilizado como símbolo y remite, más allá de su materialidad, a la vida de los personajes. Así, en El volumen de la ausencia (1985), que narra las cuatro horas y media que dura el paseo-viaje de la protagonista en la ciudad de Barcelona desde lo alto de la calle Muntaner hasta el Puerto, ese tránsito no solo es la excusa para recorrer la vida de la protagonista, sino que alude también al «viaje interior» que esta realiza.

\footnotetext{
40 Algunos autores señalan que los personajes no pueden tener una visión de conjunto de su vida porque están inmersos en ella. «We see a meaning that is only accessible to one who stands outside the fictional world. It does not exist in our "primary engagement" with the contingency of events and the unfolding of personality. It has to do with our contemplation of the novel as a unity, a work of art, our attention to the way that parts of the novel unite into a larger whole - in this case in a symbolic way» (Palmer, 1992: 146) No obstante, el método que adopta Mercedes Salisachs al escribir, muchas veces rememorando el pasado desde la distancia, sí permite a los personajes juzgar acciones pasadas con perspectiva.
} 
En relación con el espacio, considerando la producción literaria de la novelista en su conjunto se puede afirmar que, aunque muchas de sus novelas se sitúan en España y, preferentemente, en Cataluña, hay abundantes referencias cosmopolitas mostrando, por una parte, su conocimiento de variados ambientes $y$, por otra, una sociedad globalizada en la que todo influye en todos ${ }^{41}$. No obstante, en ese marco contextual que la escritora dibuja con precisión para facilitar la identificación con lo que viven los personajes, lo fundamental es el dibujo del ser humano, no solo en las novelas de corte realista, sino también en aquellas que pueden ser consideradas fantásticas o de corte más intelectual ${ }^{42}$.

\section{c) El uso poético del lenguaje.}

La prosa de Mercedes Salisacsh exhibe una gran riqueza estilística. Es fruto del gran amor por la palabra que ella dice que todo escritor debe experimentar, y consciente de que son un medio para abrir horizontes mentales y filosóficos, afirma buscarlas con cuidado, jugar con ellas y guardarlas como si fueran humanas (2003: 60-61). Por ello, en sus obras los recursos retóricos juegan un papel importante para enriquecer la capacidad léxica de la lengua y situar al lector en un plano emotivo-imaginativo que le permita re-crear el relato.

Como indica en La palabra escrita, las metáforas insinúan mucho más que lo que la afirmación explícita pudiera señalar (2003: 39) por lo que son un recurso frecuente del que la novelista se vale cuando escribe en $3 .^{\mathrm{a}}$ persona para situar al lector en el estado emocional de los personajes evitando la descripción directa $\mathrm{o}$, en los relatos en $1 .^{\mathrm{a}}$ persona, para reflejar de modo plástico las reflexiones o sentimientos del protagonista:

Ni siquiera yo mismo había experimentado a fondo aquella clase de condena sin cárcel, que convertía el ser humano en un paria ambulante paseando su nada por una selva civilizada que, lejos de oler a bosque, lanzaba vahos de gasolina y trazaba caminos grandilocuentes hacia el mal vivir, mientras pisaba un césped hecho de asfalto (2013: 223) .

${ }^{41}$ Este constituye uno de los temas más queridos de la autora, muy ligado a su concepción de la responsabilidad. En una entrevista mantenida con ella en 1999, afirmaba: «todo influye en todo, pero que lo importante está en saber manipular o situar esa influencia» (Entrevista inédita mantenida con Mercedes Salisachs el 23 de enero de 1999 en su residencia).

42 Juan Luís Alborj, refiriéndose a Primera mañana última mañana indica que «el mundo que circunda a Doquimasia, y él mismo, son de su tiempo y su país, pero su humana condición esencial no descansa en especiales emplazamientos geográficos o cronológicos» (1962: 387).

${ }^{43}$ Contrastan las metáforas tomadas de corrientes filosóficas en las novelas de corte más intelectual con las metáforas extraídas el mundo natural que predominan en la mayoría de las obras. Esta disparidad se puede apreciar comparando cómo se definen a sí mismos 
Con frecuencia se emplean metáforas o comparaciones tomadas del mundo natural o científico tanto para describir realidades sociales — «Nada importaba que España respirase con un solo pulmón: la vida continuaba y el oxígeno también podía adquirirse con aturdimientos» (Salisachs, 1996: 98)-, como situaciones personales: «El rencor que se iba apoderando de mí como una gangrena» (2004b: 198). Incluso los sentimientos más profundos se expresan a través de reacciones físicas: «Le brotaba el frío, y el temblor y aquellas ráfagas eléctricas que se apoderaban de su cuerpo cuando surgían las dudas» (1998: 48).

Es posible observar, también, el recurso a elementos naturales en el uso de personificaciones: los sauces lloran, el agua da zarpazos y grita (Salisachs, 2002: 189-190)... La danza de los salmones es en su totalidad una alegoría sobre lo que la naturaleza impone en la vida y el sentido de una lucha que termina en la muerte.

Junto a metáforas, alegorías y comparaciones, son frecuentes las antítesis: amanecidas que son noches (Salisachs, 1973: 161), sueños convertidos en pesadillas (2011: 70), silencios elocuentes (2014: 314) y ruinas que llegan a ser palacios (1998: 292) que presentan, con gran expresividad, los contrastes de la vida.

En ocasiones, Salisachs hace un uso de las cantidades de medida que desborda lo material, ya se refiera a distancia, capacidad o tiempo. Así, habla del volumen de la ausencia, el caudal de las noches vacías, la eternidad de un día o el quedarse «a cientos de kilómetros sin retorno [...] y a un milímetro de la soledad más completa» (1996: 312).

Algunos elementos tienen carácter de símbolo. Las adelfas, por ejemplo, se mencionan en varias obras llamando la atención sobre su carácter venenoso pese a su apariencia bella (Salisachs, 2009: 60 y 252) ${ }^{44}$. De modo especial los títulos de las novelas están cargados de simbolismo. Para la escritora, «el título de una novela es algo parecido al telón de un escenario» (2003: 95): un telón hecho de palabras que tiene como función despertar el interés del lector. Como ejemplos, La estación de las hojas amarillas alude a la edad otoñal de la mujer (1966: 232); La sinfonía de las moscas (1982b) se refiere a la trama de la vida de los seres insignificantes, vulgares (Alborj, 1962: 398); La voz del árbol remite al árbol de la cruz o a la voz de Dios en la conciencia que acompaña la vida de la protagonista haciéndose explícita al final de cada capítulo ${ }^{45}$.

Rómulo Doquimasia y Cecilia, protagonistas de Primera mañana última mañana y La estación de las hojas amarillas respectivamente. Rómulo se identifica como «un sintético puro» (1999: 10) y Cecilia escribe a su hermana declarando: «era únicamente tu placenta» (1982: 10).

44 Véase también Salisachs (1973: 209 y 2014: 331).

45 Al simbolismo del árbol se alude con frecuencia en la propia obra: «en su mente siempre había predominado la idea de que aquel árbol tenía su raíz invertida, que nacía en 
En conjunto, la construcción de un lenguaje literario que interpele la imaginación del lector y le conduzca a experimentar emociones y vislumbrar nuevos significados, es un elemento clave que Salisachs encamina a que el lector recree de algún modo la vivencia de los personajes.

Además de la modalización, la gestión de espacio y tiempo, y el uso poético del lenguaje, hay otro aspecto que merece atención y al que Mercedes Salisachs también se ha referido: el modo abierto en que concluyen sus obras de ficción. Se trata de un recurso técnico que ayuda a la reflexión ${ }^{46}$ pero constituye, también, la evidencia de una convicción de la escritora, que afirma que los «finales tránsito» son los únicos legítimos en la novela «ya que en el mundo nada se acaba: todo está pendiente de evolución»(Salisachs, 1966: 231).

Como se ha expuesto hasta aquí, para Mercedes Salisachs novela y vida comparten protagonista: el ser humano. Un hombre/mujer situado en un tiempo y un ambiente determinado que condicionan su existencia, en relación con otros seres humanos, actuando o dejando de hacerlo movido por propósitos no siempre evidentes que necesitan de la reflexión para ser puestos de manifiesto y, finalmente, valorados. Sus acciones, experimentadas en la inmediatez y contempladas desde la distancia, se ponen en escena a través de la forma más adecuada, en cada momento, al carácter de los protagonistas y al mensaje que se desea transmitir. Una representación concreta de la vida escondida tras un título que, como un cortinaje de palabras, cubre el escenario en el que pronto podrá adentrarse el lector.

\section{UNA NARRATIVA QUE INVITA A LA REFLEXIÓN MORAL}

¿Pueden ser estas novelas un recurso para la filosofía moral tal y como sugiere Martha Nussbaum? ¿Constituyen, al menos, una ocasión de reflexión sobre la vida buena para sus lectores?

Este, al menos, es el propósito de Mercedes Salisachs para quien escribir es un medio para objetivar fuera de sí «las razones que todos vivimos pero que, por considerarlo "corriente o vulgar o irrelevante", no nos detenemos a sopesar» (2003: 45). Estima que esta reflexión, si bien parte del autor, implica al lector invitándole a considerar la vida que se desarrolla ante sus ojos. Y, precisamente, esta posibilidad de la novela de dar claves para la vida además de

lo alto, más allá de las nubes y del sol. Para ella siempre había sido un árbol que se nutría de estrellas y que el él llegó Dios a la tierra para salvar a la humanidad y llenarla de esperanza» (Salisachs, 1998: 220)

46 «He apuntado la conveniencia de que tanto los principios de los capítulos como los finales, dejen suspendidas situaciones que inciten al lector a hacerse a sí mismo preguntas y respuestas que lo mantengan en el interés de lo que está leyendo» (Salisachs, 2003a: 79). 
proporcionar un goce estético, es lo que hace, a juicio de la escritora, que la obra sea considerada valiosa (170-171). Por ello Salisachs, presupone un lector implícito $^{47}$ atento y reflexivo, capaz de llenar los vacíos, y preguntarse, y se queja de los lectores que solo buscan una historia entretenida sin adentrarse en el discurso que les conduciría a experimentar determinadas emociones y a plantearse los problemas humanos.

La novelista es consciente de su responsabilidad. Sabe que incluso en las novelas realistas, aunque pretenda presentar «la historia [...] sin disfraces ni remiendos falseados» ${ }^{48}$, el modo de decir del autor tiene una influencia decisiva en la reflexión de lector:

Aunque no lo pretendamos también imbuimos, influimos, orientamos o desorientamos, encauzamos y sugerimos y, algunos escritores incluso llegan a dominar a los que le están leyendo. Y eso, para los escritores que tienen conciencia, implica a mi juicio, una grave obligación moral ${ }^{49}$.

El modo en que la novela promueve la reflexión requiere la identificación imaginativa del lector que se imbuye en la historia presentada entendiendo a los personajes como humanos semejantes al él y valorando sus acciones y el

47 José Ángel García Landa llama la atención sobre la posibilidad de que un texto esté destinado a más de un lector implícito en función de los sentidos intencionales que le confiera el autor (2009-2010: 72). En el caso de las novelas de Salisachs, la repetición de algunos personajes, fechas determinadas, o hechos aparentemente triviales en obras diversas, permite presuponer que, al menos en la intención de la autora, hay dos lectores implícitos: el que conoce su producción y es capaz de establecer relaciones entre el sentido de varias obras y un lector implícito más «público» En cualquier caso el lector implícito de todas las novelas de Salisachs es un lector reflexivo y atento.

${ }^{48}$ Mercedes Salisachs. «Una sola semilla para varios frutos»..., p. 11, referencia completa vid. supra nota 25. Mercedes Salisachs considera que vivimos en un mundo de profunda desorientación en el que se han perdido los valores fundamentales. De ahí su presentación, siempre delicada pero cruda, de realidades que, de algún modo, critica. Quiere reflejar una sociedad que califica de engañosa tras el espejismo del progreso y el bienestar: «nuestra lamentable realidad tan abrumada de equívocos a fuerza de querer "aparentar" [comillas en el original] sin admitir que tras esa máscara aparente y radiante, puede esconderse un nido de podredumbre» (ibíd., 11-11 bis).

49 Mercedes Salisachs. «Vejez y literatura»..., p. 18, referencia completa vid. supra nota 12. La novelista catalana se refiere en varias ocasiones a la influencia del escritor que, más allá de transmitir, puede modificar puntos de vista esenciales (2003a: 44) puesto que, como afirma Frank Palmer, todo lo que narra está imbuido de su propia percepción moral: «no matter how "impartial" the narration, there is necessarily a moral perspective, given that the narrator has subsumed the actions of the characters under particular descriptions and has selected some events rather than others for our attention, thus stipulating the focus of our concern with those characters. In so far as we accept the narrator we come to share that perception, at least for the purposes of the work, and see the characters through his eyes» (1992: 122). 
curso de su vida ${ }^{50}$. Salisachs, para lograrlo, intenta suscitar la experiencia del que se sumerge en la lectura:

Intento siempre que, cuando alguien se introduzca en el libro, consiga asimismo, experimentar y captar en sus propios sentidos, lo que los personajes oyen, huelen, ven, tocan y saborean (2003: 24).

Cuanto mayor sea el detalle y más rica la experiencia humana que se muestre al lector mayor será, también, su participación en esa experiencia. Por ello Mercedes Salisachs no elude ningún tema que considere de actualidad. No obstante tampoco cae en descripciones chabacanas o de poco gusto ${ }^{51}$. Más bien sugiere, evoca muchas veces a través del uso de metáforas que no solo suscitan la implicación sensorial sino también la emocional (Salisachs, 2003: 24) ${ }^{52}$. Salisachs intenta producir la emoción con sobriedad, «con gran escasez de palabras. Casi al modo de un impacto, y reduciendo en lo posible la explicación que precisa» (2003: 165). Es esa implicación emocional, vivida en primera persona pero, paradójicamente, con la distancia de lo que no es propio ${ }^{53}$, lo que facilita a los lectores que puedan «reflexionar sobre sus propias acciones, sus fracasos, sus aciertos y sus razones ocultas que, con frecuencia, adormecen para no sentirse culpables» (2003: 59).

No siempre la novelista procura la identificación con los personajes; en ocasiones es la confrontación con caracteres o modos de vida no deseables lo que incita la reflexión (2003: 156). El contraste entre lo bueno y lo malo, la

${ }^{50}$ «Siempre he pretendido que el lector se sienta obligado a meditar, que dialogue con los personajes, que los contradiga o les dé la razón. En una palabra, que viva la lectura, que imagine» («Mercedes Salisachs afirma que pretende que el lector se vea obligado a meditar», El Pais. 29 de octubre de 1998, <http:/elpais.com/diario/1998/10/29/cultura/909615603_ 850215.html> [ref. de 17/03/2017]).

${ }^{51}$ En la entrevista realizada por Ayuso en 2007 se refería así a su modo de describir la actualidad: «Lo que nunca hago es describir cosas que pueden herir al lector [...]. Yo procuro que, aunque escriba de una forma que sea muy cruda, jamás haga daño a nadie. Pero si expongo esos temas es porque existen. Me sirvo de ellos para alertar al lector. Nunca para ensalzarlos» (Ayuso, 2008). Esta delicadeza en el modo de escribir es puesta de relieve también por los críticos que reconocen en sus novelas «historias desgarradoras, inspiradas en duras situaciones reales, que ella traslada al papel sin retroceder ante las tragedias, pero también con una sensibilidad que no tiene nada que ver con la explotación tremendista de otros» (Pujol, 2008).

52 La escritora se refiere a emociones como angustia, alegría, miedo, seguridad y vulnerabilidad.

${ }^{53}$ Este desdoble que se produce en el lector es interpretado por los teóricos de la literatura, como un elemento fundamental para que se produzca una comprensión de la realidad. «The fact that we are in one way "drawn into" and in another way distanced from the objects of aesthetic contemplation means that we can be acquainted with things which if the acquaintance were actual might give rise to emotions or predicaments that would be a bar to this kind of understanding» (Palmer, 1992: 203). 
complejidad de las situaciones humanas que en sus continuas incursiones a la conciencia de los personajes la escritora va poniendo de relieve, y la experiencia de «ver» adónde conducen unas u otras decisiones, guían el pensamiento de un modo sutil sin obligar a una disquisición teórica. La escritora reconoce que ciertas frases, aunque se sugieran sin darles demasiada importancia, obligan a su consideración; sin embargo, «las reflexiones que el lector pueda extraer de lo que escribimos, deben brotar, sobre todo, del conjunto de la obra» (2003: 171). En ella, de algún modo se revela el sentido y el sinsentido del acontecer humano de un modo que la inmediatez de la experiencia cotidiana no permite apreciar (2003: 148) ${ }^{54}$. Esta visión de la vida como una unidad, que requiere perspectiva, es comparable a la que una persona puede tener al final de la misma o en un momento importante que cierra existencialmente una etapa. No es extraño, por tanto, que obedeciendo a este propósito muchos de los protagonistas de las novelas de la escritora barcelonesa sean personas mayores o rememoren desde la distancia acontecimientos pasados. De ese modo, no solo el lector, sino de modo ficticio los personajes mismos, pueden descubrir mejores y peores realizaciones posibles de la existencia humana ${ }^{55}$.

Una característica importante de las novelas de esta autora, a la que ya se ha aludido, son sus finales abiertos. Si bien antes se subrayaba el paralelismo entre esta estructura y la vida humana, siempre en constante cambio, esta forma de concluir las novelas sin resolver las cuestiones en conflicto obedece también al modo en que Mercedes Salisachs entiende que el escritor debe influir en el lector: presentando, no imponiendo ${ }^{56}$. No se decanta por lo que piensa

${ }^{54}$ Frank Palmer, a propósito de esta visión con perspectiva, afirma que «with fiction, and more particularly with great literature, we do seem to gain some intimation of a world seen sub specie aeternitatis. We can see a fictional world also from the outside. But this vision, in which ethics and aesthetics seem to merge, is not a vision confined to our experience of art» (1992: 150).

${ }^{55}$ María del Mar Mañas, en un artículo publicado en Espéculo, se refiere a las frecuentes analepsis que emplea la escritora barcelonesa señalando lo que, para ella, son luces y sombras de este procedimiento (2008). Independientemente del juicio que pueda merecer el uso de este recurso, el propósito de Mercedes Salisachs es evidente: llamar la atención sobre cómo un conocimiento más profundo de las circunstancias y de las consecuencias de las acciones humanas, puede variar su valoración.

${ }^{56}$ Por ello, puede suponerse equivocado el juicio de Juan Luís Alborj que, refiriéndose a Carretera intermedia, afirma que Mercedes Salisachs elude dar respuesta a los problemas, aprovechando su pericia narrativa para cortar el nudo en un cómodo desenlace cuando se presenta el conflicto moral: el amor entre dos personas que tienen sus respectivos cónyuges en el cual se interponen las exigencias religiosas de la mujer. La cuestión queda zanjada con un accidente en el que muere el enamorado que iba a encontrarse con su amada. Concluye Alborj: «El drama en ciernes, bien planteado, podría ser profundo; pero la novelista lo elude [...]. El drama sangriento elimina al más hondo, al que pudo arraigar en más impalpables pero profundas tierras» (1962: 489). No obstante, este final de la novela catalana no obedece a comodidad o falta de compromiso con la valoración moral de la autora. Al con- 
que debería hacerse sino que presenta el drama de la decisión humana en las circunstancias concretas y deja también al lector en el conflicto de valores para que, al concluir la lectura, haga su propia reflexión sobre las cuestiones que el argumento ha puesto en evidencia. Así, sin verse implicado emocionalmente en primera persona, pero comprendiendo emocionalmente las situaciones vividas por los personajes, puede juzgar cuál sería la decisión mejor.

Mercedes Salisachs considera que, a la reflexión y el juicio, cuando se ha dado una auténtica experiencia en el relato, siguen disposiciones que pueden orientar la acción:

Los libros, si gustan, deben saborearse, reflexionar sobre ellos y digerirlos con reposo para que no se indigesten. De las buenas digestiones salen las buenas disposiciones $^{57}$.

De este modo cumple su propósito que entraña una responsabilidad moral con sus lectores y hacia la sociedad: "Yo no me considero capaz de cambiar el mundo, pero sí de "poner delante" para que la gente pueda cambiar» ${ }^{58}$.

\section{CONCLUSIÓN}

El camino recorrido con Mercedes Salisachs nos ha conducido de la consideración de los aspectos temáticos de sus novelas a los elementos de los que se sirve para la construcción de un relato que promueva la reflexión del lector. Se ha puesto de relieve su propósito de que, a través de las páginas de sus obras de ficción, el lector se re-conozca como ser humano semejante a otros seres humanos que viven en contextos determinados — unas veces elegidos y otros no- y que tienen que decidir cómo responder a las diversas situaciones atendiendo a los propios valores, muchas veces en conflicto.

El planteamiento de «temas perennes» en la reflexión filosófica, el detalle en la descripción de los contextos, la atención que presta al mundo interior de los personajes y la importancia que concede a la vida emocional como elemento de la vida humana, muestra cómo su consideración de lo que hace valiosa a una novela guarda una estrecha relación con las condiciones de las obras que Martha Nussbaum considera potenciales aliadas de la filosofía moral.

trario, es expresión de su propósito al escribir puesto que no busca dar respuestas sino suscitar preguntas. Explícitamente Salisachs, a propósito del modo en que concluye otra obra, Vendimia interrumpida, se refiere a la importancia de dejar los finales abiertos para posibilitar la reflexión del lector (1966: 231).

${ }^{57}$ Mercedes Salisachs. «Vejez y literatura»..., p. 17, referencia completa vid. supra nota 12 .

58 Entrevista realizada a la autora en enero de 1999. La transcripción de la misma, junto con documentos recopilados en otras entrevistas, se conserva en mi archivo personal. 
Reconocida esta idoneidad de modo general, la fuerza de cada una de las novelas de Salisachs para promover la reflexión moral dependerá, en gran parte, de su calidad literaria, pero también de la actitud del lector y de su disposición a llenar los vacíos y preguntarse por el sentido global, con el que puede o no estar de acuerdo. Cuando esa reflexión se produce y surge la pregunta «¿qué vida es deseable para el ser humano?», independientemente de que la respuesta del lector coincida con el sentido sugerido por la obra, la novela habrá conferido una experiencia valiosa desde la perspectiva aristotélica.

Para Nussbaum, para Salisachs, a la reflexión debe seguir el deseo, y a este, la acción. Reflexión, deseo y forma de vida que puede ser contrastado y compartido en una amplia comunidad de lectores, estableciendo esa relación fructífera entre la literatura y la filosofía moral que propone Martha Nussbaum y que responde plenamente al propósito de Mercedes Salisachs: «Escribir para triunfar es escribir para el olvido. Escribir para ayudar, es triunfar en el recuerdo» (Salisachs, 2003: 193).

Es cierto que del conocimiento y el deseo a la acción queda todavía un importante paso, pero este ya no está al alcance del novelista, ni del filósofo moral, ni del educador, sino que es patrimonio de cada persona en particular.

\section{BibLiografía CITADA}

Alborj, Juan Luis (1962). Hora actual de la novela española. Madrid: Taurus.

Asís, María Dolores de (1996). Última hora de la novela en España. Madrid: Eudema.

Ayuso, Antonio (2008). «Epílogo: Mercedes Salisachs habla de su obra (entrevista inédita a la autora», Espéculo: Revista de estudios literarios. 38, [s. p.], <http://www.ucm.es/info/ especulo/msalisac/epilogo.html> [ref. de 17/03/2017].

Booth, Wayne (2005). Las compañias que elegimos. Una ética de la ficción. México: Fondo de Cultura Económica.

Castillo, Debra (1998). «Mercedes Salisachs, Ideal Womanhood, and the Middlebrow Novel», en Jeanette P. Brownlow y John Kronik (ed.), Intertextual Pursuits: Literary Mediations in Modern Spanish Narrative. London: Bucknell University Press, pp. 97-125.

Domingo, José (1973). La novela española del siglo XX, Tomo II: De la postguerra hasta nuestros días. Barcelona: Labor.

Fuente, Inmaculada de la (2002). Mujeres de la posguerra. Barcelona: Planeta.

García Landa, José Ángel (1998). Acción, relato, discurso. Estructura de la ficción narrativa. Salamanca: Universidad de Salamanca.

García Landa, José Ángel (2009-2010). «Múltiples lectores implícitos», Cuadernos de Investigación Filológica. 35-36, pp. 63-75.

Garrido, Antonio (coord.) (1997). Teorías de la ficción literaria. Madrid: Arco Libros.

Laguna, Encarnación (2008). «Mercedes Salisachs: La estación de las hojas amarillas», Espéculo: Revista de estudios literarios. 38, [s. p.], <http://www.ucm.es/info/especulo/ msalisac/e_laguna.html> [ref. de 17/03/2017].

Lamarque, Peter y Stein Haugom Olsen (1996). Truth, fiction, and literature: a philosophical perspective. Oxford: Clarendon Press. 
Mañas, María del Mar (2008). «La Gangrena y Bacteria mutante: el "naturalismo espiritual" de Mercedes Salisachs», Espéculo: Revista de estudios literarios. 38, [s. p.], <http:// www.ucm.es/info/especulo/msalisac/m_manas.html> [ref. de 17/03/17].

Mendelson-Maoz, Adia (2007). «Ethics and Literature», Philosophia. 35, pp. 111-116. doi: 10.1007/s11406-007-9068-6.

Morocco, Glenn y Janet Pérez (2002). «Mercedes Salisachs», en Janet Pérez y Maureen Ihrie (ed.), The Feminist Encyclopedia of Spanish Literature. Tomo 2, N-Z. Westport, CN y Londres: Greenwood Press, pp. 537-541.

Nussbaum, Martha C. (1995a). La fragilidad del bien: fortuna y ética en la tragedia y la filosofia griega. Madrid: Visor.

Nussbaum, Martha C. (1995b). «La imaginación literaria en la vida pública», Isegoría. 11, pp. 42-80. doi:10.3989/isegoria.1995.i11.254

Nussbaum, Martha C. (1997). Justicia poética: la imaginación literaria y la vida pública. Santiago de Chile: Andrés Bello.

Nussbaum, Martha C. (2005). El conocimiento del amor. Madrid: Machado Libros.

Nussbaum, Martha C. (2008). Paisajes del pensamiento. Barcelona: Paidós.

Palmer, Frank (1992). Literature and Moral Understanding. Oxford: Clarendon Press.

Pedraza, Felipe B. y Milagros Rodríguez (2000). Manual de literatura española. Posguerra: narradores, vol. XIII. Estella: Cénlit Ediciones.

Pujol, Carlos (2008). «Briznas de la memoria», Espéculo: Revista de estudios literarios. 38, [s. p.], <http://www.ucm.es/info/especulo/msalisac/c_pujol.html $>$ [ref. de 17/03/17].

Salisachs, Mercedes (1966). «Mercedes Salisachs», en El autor enjuicia su obra. Madrid: Editora Nacional, pp. 215-236.

Salisachs, Mercedes (1973). Adagio confidencial. Barcelona: Planeta.

Salisachs, Mercedes (1982a). La estación de las hojas amarillas. 7. a ed. Barcelona: Argos-Vergara. Primera edición de 1963.

Salisachs, Mercedes (1982b). La sinfonía de las moscas. Barcelona: Planeta.

Salisachs, Mercedes (1985). El volumen de la ausencia. Barcelona: Planeta.

Salisachs, Mercedes (1996). Bacteria mutante. Barcelona: Planeta.

Salisachs, Mercedes (1998). La voz del árbol. Barcelona: Plaza \& Janés.

Salisachs, Mercedes (1999a). Primera mañana, última mañana. 4. ${ }^{\mathrm{a}}$ ed. Barcelona: Plaza \& Janés. Primera edición de 1955.

Salisachs, Mercedes (1999b). Una mujer llega al pueblo. 12." ed. Barcelona: Plaza \& Janés. Primera edición de 1957.

Salisachs, Mercedes (2002). La conversación. Barcelona: Ediciones B.

Salisachs, Mercedes (2003). La palabra escrita. Barcelona: Ediciones B.

Salisachs, Mercedes (2004a). La gangrena. Barcelona: Planeta. Primera edición de 1975.

Salisachs, Mercedes (2004b). El último laberinto. Barcelona: Planeta.

Salisachs, Mercedes (2007). El declive y la cuesta. Barcelona: Ediciones B. Primera edición de 1966.

Salisachs, Mercedes (2009). Goodbye, España. Madrid: MR Ediciones.

Salisachs, Mercedes (2011). El cuadro. Madrid: Libros libres.

Salisachs, Mercedes (2013). El caudal de las noches vacias. Madrid: MR Ediciones.

Sánchis, Luz (2003). «Mercedes Salisachs se pasa al relato infantil a los 87 años», El Periódico de Aragón. 7 de diciembre, < http://www.elperiodicodearagon.com/noticias/escenarios/mercedes-salisachs-pasa-relato-infantil-87-anos_90388.html> [ref. de 17/03/2017].

Valbuena, Ángel (1983). Historia de la literatura española. María del Pilar Palomo (ed.); 9. ${ }^{a}$ ed. Barcelona: Gustavo Gili.

Villanueva, Darío (1995). El comentario de textos narrativos: la novela. 3. a ed. Gijón: Jucar. 
Zatlin, Phyllis (1987). «Women Novelist in Democratic Spain: Freedom to Express the Female Perspective», Anales de la literatura española contemporánea. XII, 1, pp. 29-44. Zatlin, Phyllis (2008). «Mercedes Salisachs, novelista de su época», Espéculo: Revista de estudios literarios. 38, [s. p.] <http://www.ucm.es/info/especulo/msalisac/p_zatlin.html> [ref. de 17/03/2017].

Fecha de recepción: 10 de diciembre de 2014.

Fecha de aceptación: 26 de junio de 2015. 